\title{
EVALUATION OF MECHANICAL AND ENGINEERING PROPERTIES OF VOLCANIC ROCKS
}

\author{
M. Mucella Canbay, Cengiz Kurtulus, Sefik Ramazanoglu
}

Original scientific paper

In order to determine the mechanical and engineering properties of volcanic rocks located in the Armutlu Peninsula, ten samples were collected from various locations in the investigation area and subjected to laboratory tests. Their uniaxial compressive strength (UCS), point load strength $I S_{(50)}$, ultrasonic pulse velocity $(U P V)$ and density $(d)$ were determined. Later statistical correlations were conducted by regression analysis to evaluate relationships between $U P V$ and $U C S, I s_{(50)}$ and $(d)$. The engineering properties of core samples such as brittleness $(B)$, fracture toughness $(F T)$ and drillability index $(D I)$, were determined using UCS. The hardness (Schmidt's Rebound Number) was determined using Schmidt hammer and correlated with UPV. In addition, the abrasion loss of the volcanic samples was determined. Very significant relations were obtained between $U P V$ and mechanical and engineering properties of the volcanic rocks. Seismic refraction and resistivity methods were applied to figure out the dynamic properties of volcanic rocks.

Keywords: mechanical i physical properties; seismic; volcanic rocks

Procjena mehaničkih i tehničkih svojstava vulkanskih stijena

Izvorni znanstveni članak Kako bi se odredila mehanička i tehnička svojstva vulkanskih stijena u poluotoku Armutlu, prikupljeno je deset uzoraka s raznih lokacija na istraživanom području i laboratorijski ispitivano. Određena je njihova jednoosna tlačna čvrstoća (UCS), čvrstoća u točki opterećenja $I s_{(50)}$, ultrazvučna brzina impulsa $(U P V)$ i gustoća $(d)$. Kasnije su statističke korelacije provedene regresijskom analizom kako bi se odredili odnosi između $U P V$ i $U C S, I s_{(50)}$ i $(d)$. Tehnička svojstva kao što su lomljivost $(B)$, lomna žilavost $(F T)$ te indeks bušenja $(D I)$ određeni su primjenom $U C S$. Tvrdoća (Schmidt's Rebound Number) je određena pomoću Schmidt čekića i dovedena u korelaciju s $U P V$. Pored toga određen je gubitak zbog abrazije uzoraka vulkanske stijene. Dobiveni su vrlo značajni odnosi između $U P V$ te mehaničkih i tehničkih svojstava vulkanskih stijena. Primijenjene su metode seizmičke refrakcije i otpornosti da bi se izračunala dinamička svojstva vulkanskih stijena.

Ključne riječi: mehanička i fizička svojstva; seizmički; vulkanske stijene

\section{Introduction}

The volcanic rocks in the Armutlu peninsula were studied using geophysical and geotechnical methods. The studies have been limited to massive, easily characterized and strong rocks. This paper focuses on the characterization of volcanic rocks. The specimens were gathered from the host rock-mass for laboratory tests to provide key data to evaluate the performance of the engineered structure during construction and operation phases. This included geotechnical and geophysical measurements on the volcanic rock specimens. The results presented are dry density, uniaxial compressive strength, point load strength, brittleness, sonic velocity, fracture toughness, drillability, and Schmidt hardness $[1 \div 4]$.

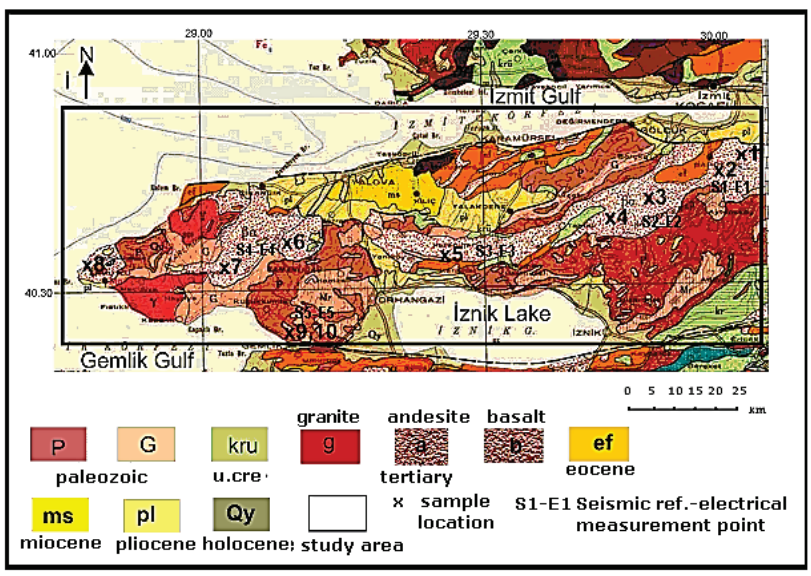

Figure 1 Generalized geological map of the Armutlu Peninsula [6]
The data from the laboratory tests obtained in this paper have been analysed for a series of relationships between the parameters including density, uniaxial compressive strength, point load strength and sonic velocity [1]. The paper presents a number of bivariate plots and relationships for the laboratory dry density and sonic velocity, uniaxial compressive strength and sonic velocity, point load strength and sonic velocity, brittleness and sonic velocity, fracture toughness and sonic velocity, drillability and sonic velocity, and Schmidt hardness and sonic velocity.

\section{Geological setting}

Recent studies on the Armutlu Peninsula have revealed that the region may be divided into three geological different zones as northern, central and southern [5]. Paleozoic aged gneiss, schists, marble and other metamorphic rocks outcrop southeast and south of the peninsula. Upper Cretaceous aged rocks, mainly carbonates, outcrop southeast and central area of the study area. The Middle Eocene volcanic rocks are widespread in all the three zones. The volcanic rocks are exposed preferentially along the E-W direction, which were formed during the Tertiary. These volcanic rocks intercalate with the shallow marine clastic rocks and carbonates. The volcanic rocks are mainly composed of the andesitic lavas and associated with pyroclastic rocks. In addition to these, lavas of varying petrological range, include basalt, basaltic andesite, dacite and riodacite. In the study area, the andesites occur as lava flows, which alternate with ash and block tuffs and the ash-fall tuffs of intermediate composition. The basic rock occurs in both 
of lava flows and dykes which cut the andesite. Felsic volcanic rocks occur as small domes (Fig. 1 and Fig. 2).

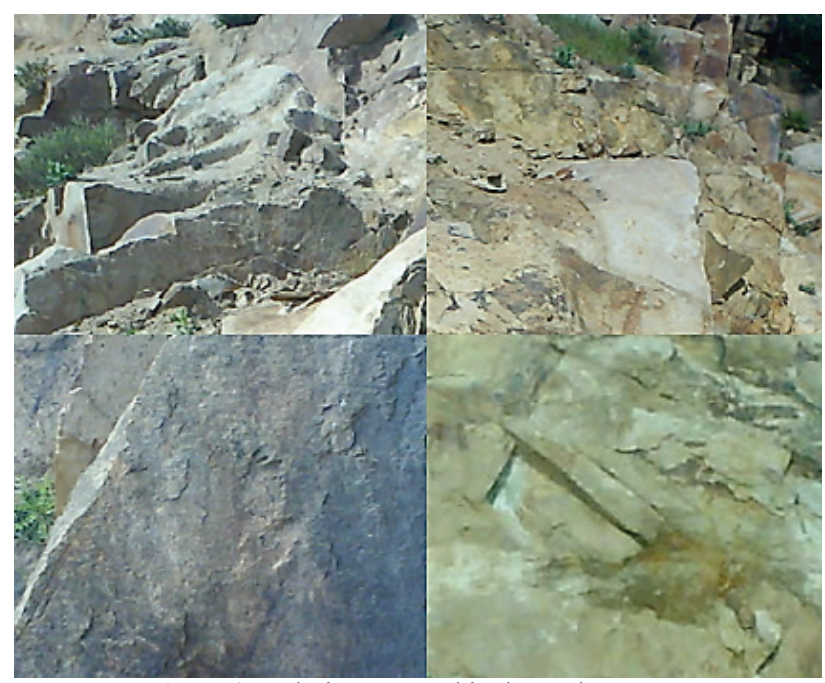

Figure 2 Andesites exposed in the study area

\section{Experımental testıng}

\subsection{Mechanical and physical characterization}

The mechanical characterization of volcanics aimed at obtaining the complete behaviour of different types of volcanics under tensile and compressive loading, thus achieving an overview of relevant engineering properties, namely modulus of elasticity, compressive and tensile strength and fracture properties. Ten volcanic specimens (1 riolite, 2 diabase, 1 andesitic basalt, 1 andesite and 5 basalt) were collected from different locations of volcanic area in the Armutlu Peninsula. The specimens used for the investigation are $54 \mathrm{~mm}$ diameter and $110 \mathrm{~mm}$ long cylindrical samples, which would be acceptable for ASTM $[7 \div 10]$, or ISRM $[11,12]$. In the preparation of the specimens, special care was taken to ensure parallel ends and perpendicular to the longitudinal axis. In addition, the specimen ends were suitably ground so that a smooth surface could be obtained. The rock strength index was obtained using the point load test [9]: The tensile strength of the test samples was determined by closed loop hydraulically operated UTEST testing machine of $200 \mathrm{t}$ capacity. Ultrasonic Pulse Velocity (UPV) measurements of compressional waves (P-waves) were conducted using DT Qust-120+ ultrasonic pulse generator instrument with the transducers having a $54 \mathrm{kHz}$ frequency. P-wave velocities were measured on specimens with a diameter of $54 \mathrm{~mm}$ and a length of $110 \div 115 \mathrm{~mm}$. The density of each core sample was measured after the removal of moisture from it. The Los Angeles abrasion tests were carried out in accordance with ASTM Method C 131-66 ([13, 14]) using course aggregates obtained from hand crushing using a hammer in Armutlu volcanic rock sites. Test samples were oven-dried at $105 \div 110^{\circ} \mathrm{C}$ for $24 \mathrm{~h}$ and then cooled at room temperature before they were tested. Grading D was used in the tests. The density of dry samples was obtained from the ratio of mass of samples to their volumes.

\section{Estimation of engineering properties}

The engineering properties of samples such as brittleness $(B)$, fracture toughness $(F T)$, drillability index
(DI) and Schmidt Rebound Number were determined using the following equations [4].

$B=\frac{U C S \times \sigma_{\mathrm{T}}}{2}$

where $B$ is brittleness; $\sigma_{\mathrm{T}}$ is tensile strength $(\mathrm{MPa})$.

$F T=0,11 \times B^{0,43}$,

where $F T$ is the fracture toughness.

$D I=0,6344 \times B^{0,6186}$,

where $D I$ is the drillability.

The brittleness of core samples varies between 34,47 and 206,05 (Tab. 1). There is a good linear relationship between brittleness and UPV. Brittleness increases with increase in $U P V$. The fracture toughness of the samples ranges between $0,50 \mathrm{MPa} \cdot \mathrm{m}^{0,5}$ and $1,11 \mathrm{MPa} \cdot \mathrm{m}^{0,5}$. The drillability of the cylindrical cores varies from 5,66 $\mathrm{kN} / \mathrm{mm}$ to $17,63 \mathrm{kN} / \mathrm{mm}$. Hardness of the core samples was determined using N-type Schmidt hammer with impact energy of $2207 \mathrm{~N} \cdot \mathrm{m}$. The Schmidt hardness of the cylindrical cores varies from 35,2 to 51,8 .

The empirical relationships between mechanical and engineering properties and $U P V$ are given in Tab. 1 .

Table 1 Empirical relationships for core samples

\begin{tabular}{|l|l|}
\hline$\rho=0,0002 \cdot U P V+1,2447$ & $R^{2}=0,91$ \\
\hline$U C S=0,0192 \cdot U P V-47,806$ & $R^{2}=0,80$ \\
\hline$I S_{(50)}=0,0023 \cdot U P V+7,0387$ & $R^{2}=0,84$ \\
\hline$T S=0,0019 \cdot U P V-4,6009$ & $R^{2}=0,76$ \\
\hline$T S=0,0981 \cdot U C S-0,0436$ & $R^{2}=0,97$ \\
\hline$B=0,0919 \cdot U P V-339,34$ & $R^{2}=0,80$ \\
\hline$F T=0,0003 \cdot \mathrm{UPV}-0,5987$ & $R^{2}=0,78$ \\
\hline$D I=0,0058 \cdot U P V-17,151$ & $R^{2}=0,79$ \\
\hline$R N=0,0065 \cdot U P V+13,135$ & $R^{2}=0,67$ \\
\hline$U C S=8,1065 \cdot I s_{(50)}-13,115$ & $R^{2}=0,88$ \\
\hline
\end{tabular}

Where $\rho$ - Density, UPV - Ultrasonic pulse velocity, UCS - Uniaxial compressive strength, $I_{(50)}$ - Point load index, $B$ - Brittleness, $R N$ Schmidt rebound number, $F T$ - Fracture toughness, $D I$ - Drillability, $T S$ Tensile strength.

Table 2 Dynamic properties of the volcanic rocks

\begin{tabular}{|l|c|c|c|}
\hline & Symbol & Unit & 1. layer \\
\hline P-velocity & $V_{\mathrm{P}}$ & $\mathrm{m} / \mathrm{s}$ & 365 \\
\hline S-velocity & $V_{\mathrm{S}}$ & $\mathrm{m} / \mathrm{s}$ & 170 \\
\hline Depth & $h$ & $\mathrm{~m}$ & 1,0 \\
\hline Density & $\rho$ & $\mathrm{g} / \mathrm{cm}^{3}$ & 1,67 \\
\hline Poisson ratio & $v$ & - & 0,36 \\
\hline Shear modulus & $G$ & $\mathrm{~kg} / \mathrm{cm}^{2}$ & 483 \\
\hline Elasticity modulus & $E$ & $\mathrm{~kg} / \mathrm{cm}^{2}$ & 1317 \\
\hline Bulk modulus & $k$ & $\mathrm{~kg} / \mathrm{cm}^{3}$ & 1584 \\
\hline Dominant period & $T_{\mathrm{o}}$ & $\mathrm{s}$ & - \\
\hline Bearing capacity & $q$ & $\mathrm{~kg} / \mathrm{cm}^{2}$ & 1,33 \\
\hline
\end{tabular}

\section{Dynamıc propertıes of the volcanıc rocks}

Dynamic properties of the volcanic rocks were determined applying seismic refraction studies at 5 points of the investigation area by a 12 channel $(\mathrm{Ch})$ Geometrics Seismic Enhancement (Smart Seis) seismograph. Compressional P-wave velocity data were recorded using 
an in-line spread of $14 \mathrm{~Hz}$, vertical component geophones spaced at 2,0 $\mathrm{m}$ intervals. P-wave energy was stacked together from 7 impacts generated by vertically striking a steel plate with an $8 \mathrm{~kg}$ sledge hammer. Shear wave data were recorded with the same seismograph using an in-line spread of $14 \mathrm{~Hz}$ horizontal component geophones spaced 2,0 $\mathrm{m}$ apart and oriented perpendicular to the profile direction. The S-wave seismic source consisted of wooden timber $(15 \times 15 \times 200 \mathrm{~cm})$ with steel caps placed on soil beneath the wheels of the vehicle at right angles to the direction of the profile. The $\mathrm{P}$ and $\mathrm{S}$ - wave velocities and other dynamic properties of the layers are given in Tab. 2.

\section{Electrical studies}

The importance of electrical survey is to determine the subsurface resistivity distribution by conducting measurements on the ground surface. From these measurements, the apparent resistivity of underground can be estimated. The ground resistivity is related to various geological parameters such as porosity and degree of water saturation, and the mineral and fluid content

In order to determine the resistivity values of the volcanic rocks, Vertical Electrical sounding (VES) was applied at 5 points at the investigation area using Schlumberger configuration.

Three layers were determined. The average resistivity and thickness of the layers are $\rho_{1}=1140 \Omega \mathrm{m}, h_{1}=0,8 \mathrm{~m}$, $\rho_{2}=4600 \Omega \mathrm{m}, \mathrm{h}_{2}=5,4 \mathrm{~m}$. The resistivity of the $3^{\text {rd }}$ layer is $\rho_{3}=5400 \Omega \mathrm{m}$. The high resistivity value $\left(\rho_{1}=1140\right.$ $\Omega \mathrm{m})$ is associated with disintegrated basalt at the surface and higher resistivity values $(4600 \Omega \mathrm{m}$ and $5400 \Omega \mathrm{m})$ are associated with the harder section of basalts beneath the disintegrated layer.

\section{Results}

The mechanical and engineering properties of volcanic rocks in the Armutlu peninsula have been determined by applying laboratory tests, using empirical equations and in situ geophysical studies, and the allowing results were obtained.

a) The laboratory experiments were performed over rock samples, geophysical seismic velocity measurements and electrical sounding (resistivity) applications were performed in-situ over the volcanic rocks.

b) The volcanic rocks exposed preferentially along the $\mathrm{E}-\mathrm{W}$ direction were formed during the Tertiary intercalate with the shallow marine clastic rocks and carbonates which are mainly composed of the andesitic lavas and associated with pyroclastic rocks.

c) Three seismic layers were found with the following $\mathrm{P}$ velocities: $V_{\mathrm{P} 1}=365 \mathrm{~m} / \mathrm{s}, V_{\mathrm{S} 1}=170 \mathrm{~m} / \mathrm{s}, V_{\mathrm{P} 2}=1850$ $\mathrm{m} / \mathrm{s}, V_{\mathrm{S} 2}=960 \mathrm{~m} / \mathrm{s}, V_{\mathrm{P} 3}=4560 \mathrm{~m} / \mathrm{s}$ and $V_{\mathrm{S} 3}=2350$ $\mathrm{m} / \mathrm{s}$. The two upper layers are composed of basalts while the third is massif basalt

d) The density of the volcanic rocks varies between 2,1 $\mathrm{g} / \mathrm{cm}^{3}$ and $2,52 \mathrm{~g} / \mathrm{cm}^{3}$. The $U P V$ ranges from 4125 $\mathrm{m} / \mathrm{s}$ to $6163,5 \mathrm{~m} / \mathrm{s}$ whereas the $U C S$ varies between $27,8 \mathrm{MPa}$ and $63,4 \mathrm{MPa}$. The $I s_{(50)}$ ranges from 2,18
$\mathrm{MPa}$ to $6,48 \mathrm{MPa}$, and tensile strength $\sigma_{\mathrm{T}}$ varies between 2,47 MPa and 6,5 MPa.

e) It is shown that UPV is closely related to uniaxial compressive strength, point load index, drillability, fracture toughness and Schmidt rebound number.

f) Three layers were distinguished in resistivity studies. Based on the observation from the surface geology the $0.8 \mathrm{~cm}$ thick first layer belongs to composed by weathered and altered rock $\left(\rho_{1}=1140 \Omega \mathrm{m}\right)$; The 5,4 $\mathrm{cm}$ thick second layer (4600 $\Omega \mathrm{m})$ and the third layer $(5400 \Omega \mathrm{m})$ are associated with the harder section of basalts.

g) The average abrasion loss values of the volcanic rocks in the Armutlu peninsula is 13,39.

\section{References}

[1] D'Andrea, D. V.; Fischer, R. L.; Fogelson, D. E. Prediction of compressional strength from other rock properties. United States Department of the Interior Bureau of Mines, Report of Investigations 6702, 1965.

[2] Hucka, V. A. A rapid method determining the strength of rocks m-situ. // Int J Rock Mech Mm Sei Geomech Abstr. 2, (1965), pp. 127-134. DOI: 10.1016/0148-9062(65)90009-4

[3] Altındag, R. The evaluation of rock brittleness concept on rotary blast hole drills. // J. South African Inst. Min. Metallurgy. (2002), pp. 61-66.

[4] Chary, K. B.; Sarma, L. P.; Prasanna Lakshmi, K. J.; Vijayakumar, N. A.; Naga Lakshmi, V.; Rao, M. V. M. S. Evaluation of engineering properties of rock using ultrasonic pulse velocity and uniaxial compressive strength. // Proc. National Seminar on Non-Destructive Evaluation, Hyderabad, Dec, 7-9, (2006), pp. 279-385.

[5] Genç, C. Ş.; Yılmaz, Y. An Example of Post-collisional Magmatism in Northwestern Anatolia: The KizderbentVocanics (Armutlu Peninsula. Turkey). // Journal of Earth Sciences / Tübitak, Turkey. 6, (1997), pp. $33-42$.

[6] Ternek, Z.; Erentoz, C.; Pamir, H. N. Explanatory Text of the Geological Map of Turkey - Istanbul Sheet, MTA Published. 1987.

[7] ASTM D4543. Standard practice for preparing rock core specimens and determining dimensional and shape tolerances. American Society for Testing and Materials. 2001.

[8] ASTM D3148. Standard Test Method for Elastic Moduli of Intact Rock Core Specimens in Uniaxial Compression. 2002.

[9] ASTM D4543-08. Standard Practices for Preparing Rock Core as Cylindrical Test Specimens and verifying Conformance to Dimensional and Shape Tolerances. 2008.

[10] ASTM D7012-10. Standard Test Method for Compressive Strength and Elastic Moduli of Intact Rock Core specimens under varying States of Stress and Temperatures. 2010.

[11] ISRM. The Complete ISRM Suggested Methods for Rock Characterization, Testing and Monitoring: 1974-2006, (Ulusay, R. and Hudson, J. A., Editors), Kozan Ofset Matbaacılik, Ankara, 2007.

[12] Ergün, T.; Nilsun, H. The effect of length to diameter ratio of test specimens on the uniaxial compressive strength of rock. // Bull Eng Geol Environ. 68, (2009) pp. 491-497. DOI: 10.1007/s10064-009-0227-9

[13] Kahraman, S.; Gunaydın, O. Empirical methods to predict the abrasion resistance of rock aggregates. // Bulletin of Engineering Geology and The Environment. 66, (2007), pp. 449-455. DOI: $10.1007 / \mathrm{s} 10064-007-0093-2$

[14] Kahraman, S.; Toraman, O. Y. Predicting the Los Angeles abrasion loss of rock aggregates from crushability index. // 
Bulletin of Materials Science. 31, (2008), pp. 173-177. DOI:

10.1007/s12034-008-0030-4

\section{Authors' addresses}

M. Mücella Canbay, grades and ranks

Kocaeli University, Engineering Faculty,

Dept. of Geophysics, 41300 İzmit-Kocaeli, Turkey

E-mail: mucella@kocaeli.edu.tr

\section{Cengiz Kurtulus, grades and ranks}

Kocaeli University, Engineering Faculty,

Dept. of Geophysics, 41300 İzmit-Kocaeli, Turkey

E-mail: cengizk@kocaeli.edu.tr

Sefik Ramazanoğlu, grades and ranks

Sakarya University, Engineering Faculty,

Dept. of Geophysics, 54187 Sakarya - Kocaeli, Turkey

E-mail: sefikr@hotmail.com 